УДК 378.6:359.3:356.1 (045)

UDC 378.6:359.3:356.1 (045)

DOI: $\underline{10.31475 / \text { ped.dys.2020.29.11 }}$

ІГОР ЗАЙЦЕВ,

доцент кафбедри

(Украӥна, Одеса, Військова акаделія (м. Одеса)

IHOR ZAITSEV,

Assistant Professor

(Ukraine, Odesa, Military Academy (city of Odesa)

ORCID: 0000-0002-0619-8148

\title{
Організаційно-педагогічні умови підготовки майбутніх офіцерів морської піхоти засобами інформаційно-комунікаційних технологій
}

\section{Organizational-Pedagogical Conditions of Training Future Naval Infantry Units Officers by Means of Information-Communication Technologies}

Трансборлаційні процеси в Украӥні потребують підвищення ефбективності підготовки майбутніх бахівців у систелі вищої освіти, зокрема і у вищих військових навчальних закладах. На сучаснолу етапі система військової освіти повинна забезпечити ефбективну підготовку майбутніх офбіцерів морської піхоти до військово-профбесійної діяльності відповідно до сучасних вимог та державних стандартів освіти. Модернізація систели вищої військової освіти України в контексті Болонської декларацї̈, інтеграція систели освіти Украӥни в европейське та світове освітне співтовариство, налагодження співпраці украӥнських вищих військових навчальних закладів із зарубіжнили партнерами із країнчленів НАТО, а також об’єтивно потреба підготовки висококваліббікованих військових фбахівиів зуловлюють потребу пошуку нових, еббективних фборм, методів, засобів, прийомів організацї освітнього процесу, рефборлування змісту військової освіти. Нині відбуваються процеси модернізаціӥ вітчизняної систели вищої військової освіти відповідно до Болонської декларації. 3 огляду на ие, важливил напрялол наукових студій законолірно стали інбборлаційно-колунікаційні технологї організацї освітнього процесу, зокрема і які використовуються при підготовці майбутніх обьиерів морської піхоти. Толу в статті здійснено аналіз основних організаційно-педагогічних улов підготовки майбутніх оббіцерів морської піхоти засобали інфборлаційно-колунікаційних технологій. Встановлено та обгрунтовано, що підготовка майбутніх офбіцерів морської піхоти до профбесійної діяльності із використаннял засобів інфорлаційно-колунікаційних технологій відбуватилеться більш ефбективно за таких організаиійно-педагогічних улов: організаиія салостійної роботи курсантів засобами ІКТ; впровадження сучасних колп'ютерно орієнтованих методів та засобів організацї̈ освітнього процесу у ВВНЗ; використання методу проєктів в професійній підготовиі майбутніх обіиерів.

Ключові слова: організаційно-педагогічні улови, підготовка, майбутні оббіцери морськоӥ піхоти, інфборлаційно-колунікаційні технологї.

Transformation processes in Ukraine need to increase the efficiency of training future specialists in the system of higher education, in particular in higher military educational institutions. At the present stage, the system of military education must ensure the effective training of future naval infantry units officers for military professional activities in accordance with modern requirements and state standards of education. Modernization of Ukraine's system of higher military education in the context of the Bologna Declaration, integration of Ukraine's system of education into the European and world educational community, setting up cooperation of Ukrainian higher military educational institutions with foreign partners from NATO member states, and objective need of training of highly qualified military specialists stipulate the need of search for new, effective forms, methods, means, ways of organizing the educational process, reforming the content of military education. Currently, the processes of modernization of the national system of higher military education are underway in accordance with the Bologna Declaration. In view of this, an important area of researches has naturally become information-communication technologies of the organization of the educational process, in particular those used in the training of future naval infantry units officers. Therefore, the article analyzes the basic organizationalpedagogical conditions of the training of future naval infantry units officers by means of informationcommunication technologies. It is established and substantiated that the training of future naval infantry units officers for professional activities with the use of information-communication technologies will be more effective under the following organizational-pedagogical conditions: organization of independent work of cadets with the use of ICT tools; introduction of modern computer-based methods and tools of organizing the educational process in higher military educational institutions; use of the project method in the training of future officers.

Keywords: organizational-pedagogical conditions, training, future naval infantry units officers, information-communication technologies. 
Вступ / Introduction. Перед сучасними вищими військовими навчальними закладами (далі - ВВНЗ) постала важлива та актуальна проблема, яка полягає у підготовці майбутніх офіцерів, здатних діяти в мінливих умовах сучасного суспільства, які здатні приймати рішення в складних ситуаціях. А тому першочергового значення набувае наявність в майбутніх офіцерів професійних знань, умінь і навичок, досвіду особистої діяльності, сформованих професійних компетентностей, практичного досвіду, яких набувають майбутні оффцери морської піхоти (далі - МОМП) під час професійної підготовки. Реформування системи військової освіти ставить важливим завданням перед науково-педагогічними працівниками удосконалення змісту підготовки, використання інноваційних, нестандартних форм, методів та засобів організації освітнього процесу. Важливим у цьому аспекті є виокремлення та обгрунтування організаційно-педагогічних умов підготовки МОМП засобами інформаційнокомунікаційних технологій (далі - IКТ), які сприятимуть підвищенню ефективності освітнього процесу у BВHЗ.

Мета та завдання / Aim and Tasks. Метою статті є на основі аналізу наукових джерел, анкетування суб̆ектів освітнього процесу у ВВНЗ виокремити та обгрунтувати діевість організаційно-педагогічних умов підготовки МОМП засобами ІКТ.

Методи / Methods. Для досягнення мети дослідження було використано комплекс взаемопов’язаних методів: аналіз, синтез, систематизація та узагальнення науково-педагогічних джерел, зокрема у сфері військової освіти, опитування, інтерв'ю, анкетування, спостереження за педагогічним процесом з метою виокремлення найбільш дієвих організаційно-педагогічних умов підготовки МОМП засобами IКТ.

Результати / Results. Системотвірним компонентом підготовки МОМП е сукупність організаційнопедагогічних умов, які забезпечать досягнення якнайкращих результатів освітнього процесу в ВВНЗ. У цілісному взаемозв'язку вони дають можливість впливу на весь освітній процес загалом, та на суб’ектів освітнього процесу зокрема (науково-педагогічні працівники, курсанти), забезпечать можливість керівництва навчально-пізнавальною діяльністю курсантів та побудувати процес професійної підготовки таким чином, щоб використовувані форми, методи та засоби забезпечили реалізацію завдань викладання освітніх компонентів освітньо-професійної програми.

Тому, на нашу думку, з огляду на вищезазначене, необхідно з’ясувати сутність дефініцій «умова», «педагогічна умова», «організаційно-педагогічна умова».

Розглянемо трактування поняття «умова» в контексті визначення цього поняття у різного роду наукових виданнях. «Філософський словник» за редакцією В. Шинкарука (Філософський словник..., 1986) трактуе термін «умова» як фактор, рушійна сила, причина будь-якого процесу; у «Філософській енциклопедії» термін «умова» розглядаеться як сукупність об’ектів (речей, процесів, відносин), які е потрібними для виникнення, існування, зміни цього об’єкта (Философоская энциклопедия, 1964, с. 286).

На думку З. Курлянд, «коли явище викликае інше явище, воно е причиною; коли явище взаемодіе з тим або іншим у процесі розвитку цілого, до якого воно належить, воно є чинником; коли явище обумовлюе існування іншого, воно е умовою» (Курлянд 3. Н., 1992, с. 57.). Таким чином, можна зробити узагальнення, що під поняттям «умова» в наукових дослідженнях слід розуміти сукупність чинників, впливів, які об’ективно впливають на результативність певного процесу.

Пов’язаним терміном із «умова» е «педагогічна умова». Зауважимо, що сьогодні низка науковців розробляе проблематику педагогічних умов забезпечення різних аспектів освітнього процесу. Так, С. Оргеєва вважае, що «педагогічні умови визначаються як сукупність об”єктивних можливостей, які забезпечують успішне вирішення поставлених завдань і їх можна класифікувати за різними аспектами: філософський; дидактичний; виховний (Оргеєва С. В., 2016). «Словник-довідник з професійної педагогіки» дае таке визначення педагогічних умов: «це обставини, від яких залежить та відбуваеться цілісний продуктивний педагогічний процес професійної підготовки фахівців, що опосередковуеться активністю особистості, групою людей» (Словник-довідник з професійної педагогіки..., 2006, с. 243). Науковець С. Гончаренко в «Українському педагогічному словнику» подає визначення терміну «педагогічні умови» як «демонстрацію сукупності процесів відношень, що необхідні для виникнення та існування певного об’екта або обставин процесу навчання, які є результатом відбору, конструювання і пристосування елементів, змісту, методів, засобів навчання для досягнення поставлених завдань» (Гончаренко С., 1997, с. 255).

Таким чином, можна стверджувати, що під поняттям «педагогічні умови» в сучасних освітніх дослідженнях слід розуміти обставини, які прямо чи опосередковано впливають на освітній процес і створення яких дає змогу реалізувати потенціал змісту навчання, форм, методів та засобів для вирішення конкретного освітнього завдання, і які загалом впливають на особистісний, процесуальний та результативний аспекти підготовки майбутніх фахівців у закладах освіти.

Варто зазначити, що в сучасному освітньому та науковому дискурсі поняття «педагогічні умови» чи «організаційно-педагогічні умови» (залежно від конкретного наукового завдання, яке ставить перед собою дослідник) використовуються в дослідженнях, які стосуються підготовки фахівців різного профілю. Так, до прикладу, на думку О. Доброштан, «організаційно-педагогічними умовами» е об’ективні можливості змісту, форм, методів, засобів матеріально-просторового середовища, ступінь готовності учасників освітнього процесу, які у своїй сукупності мають позитивний вплив на досягнення очікуваних результатів (Доброштан О. О., 2016).

3 огляду на все вищезазначене, зокрема і на погляди науковців щодо доцільності виокремлення та 
використання організаційно-педагогічних умов, нами було обрано для дослідження саме таку категорію умов.

На нашу думку, організаційно-педагогічні умови підготовки МОМП засобами ІКТ мають вагомий вплив на ефективність професійної підготовки досліджуваної категорії фрахівців, і в кінцевому результаті забезпечать готовність МОМП до професійної діяльності.

Проведений аналіз науково-педагогічних джерел дав змогу визначити низку організаційнопедагогічних умов підготовки майбутніх офіцерів Збройних Сил України до професійної діяльності із використанням засобів ІКТ. 3 метою виокремлення найбільш дієвих організаційно-педагогічних умов підготовки МОМП засобами ІКТ нами було проведено експертне опитування науково-педагогічних працівників ВВНЗ. За результатами аналізу науково-педагогічних джерел 3 досліджуваної проблеми та після обробки результатів опитування було складено перелік організаційно-педагогічних умов, які забезпечують ефективну підготовку МОМП засобами IКТ. Респондентам було запропоновано із переліку вибрати шляхом ранжування найбільш діеві на їхню думку.

Тому, на підставі вивчення науково-педагогічної літератури, нормативно-правових документів в сфрері освіти (загальнодержавних та відомчих), аналізу практики підготовки МОМП, спостереження за освітнім процесом, врахування результатів опитування виокремлено такі організаційно-педагогічні умови підготовки МОМП засобами ІКТ, як-от: організація самостійної роботи курсантів засобами ІКТ; впровадження сучасних комп'ютерно оріентованих методів та засобів організації освітнього процесу у ВВНЗ; використання методу проєктів в професійній підготовці майбутніх офіцерів.

Перша організаційно-педагогічна умова передбачала організацію самостійної роботи курсантів із використаннял засобів інборлаційно-колунікаційних технологій.

Ми виходимо із тіеї позиції, що самостійна робота курсантів посідае важливе місце в процесі професійної підготовки, і вона повинна спеціально плануватися, організовуватися та обліковуватися, і $\epsilon$ своерідним резервом підвищення ефективності підготовки майбутніх фрахівців. Використання сучасних засобів ІКТ дасть змогу їі ефективно організувати та перевірити рівень засвоєння навчального матеріалу курсантами. Окрім того, оскільки самостійну роботу курсантів організовуе науково-педагогічний працівник, курсанти здійснюють пізнання навчального матеріалу та самостійне його опрацювання, тому самостійна робота є завершальним етапом усіх видів освітньої діяльності та дає змогу забезпечити формування інтересу до майбутньої професійної діяльності; формуе навички у курсантів самостійного здобуття знань; поглиблюе та розширюе знання і кругозір курсантів, а також розвиває здібності і якості особистості, серед яких самостійність, організованість, відповідальність тощо.

Щодо можливостей використання засобів ІКТ при організації самостійної роботи МОМП, то їх можна використовувати в декількох напрямах. Перший напрям застосування IКТ в підготовці МОМП - це використання ресурсів мережі Інтернет для організацї салостійної роботи курсантів. Другий робота із електронними навчально-методичними матеріалами (електронні підручники, посібники, словники, енииклопедіï). Третій - мережеве (онлайн) консультування, яке шляхом участі курсантів у онлайн-форумах, чатах, відео- та телеконференціях, листування із викладачами та між собою.

Загалом розв'язання науково-методичних питань організації ефрективної самостійної навчальної діяльності МОМП у процесі їхньої професійної підготовки у ВВНЗ, створення відповідного організаційнометодичного забезпечення е одним із важливих завдань військової освіти України (Маслій О., 2019, с. 54).

Друга організаційно-педагогічна умова - впровадження сучасних колпютерно орієнтованих методів та засобів організацї освітнього процесу у вищих військових навчальних закладах.

Викладачі ВВНЗ повинні в повній мірі володіти знаннями про методи і засоби організації освітнього процесу, зокрема і щодо методичних особливостей їх використання під час викладання навчальних дисциплін. Комп'ютерно орієнтовані методи та засоби навчання курсантів передбачають використання IКТ. Для підготовки МОМП в процесі аудиторної роботи доцільно використовувати традиційні та комп'ютерно орієнтовані методи і засоби навчання, в той час як для організації позааудиторної роботи комп'ютерно оріентовані методи. Організовуючи подачу навчального матеріалу, зокрема використовуючи словесні методи навчання, доцільно поєднувати роботу із використанням ресурсів мережі Інтернет, електронних навчально-методичних пособників, використання спеціалізованого програмного забезпечення. Для забезпечення унаочнення подачі навчального матеріалу викладачам рекомендовано використовувати різного роду навчальне відео, зокрема і з мережі Інтернет (відеохостинги, до прикладу. YouTube). Такі методи і засоби можна використовувати при викладанні навчальних дисциплін «Загальна тактика», «Основи військового управління (у т.ч. штабні процедури НАТО)», «Військова топографрія», «Інженерна підготовка», «Стрілецька зброя та вогнева підготовка» та ін. Під час використання практичних методів навчання доцільно застосовувати спеціальне програмне забезпечення, використовувати мультимедійні презентації, відео- та аудіозаписи. На практично-семінарських заняттях, під час виконання лабораторних робіт доцільно застосувати комп'ютерні засоби навчання для проведення ділових ігор, зокрема які дають можливість виробити у майбутніх офіцерів лідерські навички, вміння управлінської діяльності, навчити діяти в умовах та ситуаціях, які близькі до реальності.

Ще один шлях використання компютерно оріентованих методів і засобів навчання передбачає проведення контролю навчальної успішності курсантів (тестування тощо). Тестування навчальних досягнень курсантів доцільно здійснювати, до прикладу, за допомогою програмного засобу TestPlayer, 
особливостями якого е: авторизація, вибір тесту; тестування за розкладом; відображення історії сеансів; режим: самоконтроль, іспит; ощінка: відсоток, клас, бал; пропуск завдань / зміна відповіді; перегляд невірно виконаних завдань; перегляд успішності по розділах тесту; відновлення сеансу тестування; локальне, Internet тестування; можливість використання не лише текстових завдань, а й графічних; відображення оцінки 3 кількістю відповідей та витраченим часом; можливість роботи над помилками; збереження результатів тестування та можливість ведення електронного журналу.

У сучасних умовах все більшої ваги набуває дистанційне навчання. Так, використання ІКТ для дистанційного навчання сьогодні має широкі можливості в структурі освітнього процесу ВВНЗ.

Дієвою та перспективною з огляду на ефективність результатів навчальних досягнень курсантів щодо здобуття знань, формування умінь та навичок є web-quest технологія, яка реалізуе навчальні завдання шляхом формулювання та вирішення певної проблеми і відбуваеться з елементами рольової гри. Для виконання таких завдань активно використовуються Інтернет-технології.

Не менш важливими комп'ютерно орієнтованими методами i засобами навчання є системи імітаційного моделювання. Так, до прикладу, в Військовій академії (м. Одеса) системи імітаційного моделювання бойових дій використовуються з широкими можливостями відтворення реальних подій на полі бою за допомогою засобів обчислювальної техніки, яка на сьогоднішній час вже стала невід’емною частиною міжнародних навчань, інших елементів бойової підготовки.

На сьогодні доцільно використовувати такі програмні продукти імітаційного моделювання бойових дій: Follow Me та Battle Command, система JCATS, система - VBS3.

Застосування імітаційної моделі загальновійськового бою як елементу фахової підготовки офіцера тактичного рівня, що відображає основні елементи цілеспрямованої діяльності командира з управління підрозділом під час бойових дій, в сукупності з класифікаційними схемами їі декомпозиції дозволяє здійснювати відбір, систематизацію та структурування знань з урахуванням їх ролі і місця у вирішенні практичних завдань, а також побудувати процес навчання, спрямований на засвоєння універсальних алгоритмів діяльності, що забезпечуе формування умінь по перенесенню засвоених знань на нові умови діяльності, розвиток творчого мислення (Кос М. В., 2018, с. 52).

Третя організаційно-педагогічна умова - використання методу проєктів в професійній підготовиі майбутніх ообіцерів - спрямована на активне впровадження в процес опанування курсантами освітніх компонентів профресійної підготовки методу проєктів.

Проєктна діяльність курсантів забезпечуе здобуття нових знань, формуе вміння пошуку інформації, дослідницькі здібності, ініціативу, відповідальність за свої дії та дії інших. Так, в процесі опанування навчальними дисциплінами курсантам пропонувалися для підготовки такі проєкти: «Історія морської піхоти в світі та в Україні», «Зброя армій світу», «Історія війн», «Надання першої медичної допомоги» та ін. Після розробки проєктів курсанти мають їх презентувати перед навчальною групою та продемонструвати свої вміння використання засобів ІКТ, а також знання, уміння і навички, які вони здобули під час підготовки певного проєкту.

Обговорення / Discussion. Значна кількість вчених наразі досліджували проблему організаційнопедагогічних умов організації освітнього процесу із використанням засобів ІКТ при підготовці фрахівців різних спеціальностей (виокремлення та обгрунтування організаційно-педагогічних умов, їх сутність, особливості їх реалізації, переваги та недоліки тощо).

Так, до прикладу, Т. Ткаченко дослідив організаційно-педагогічні умови формування професійної компетентності курсантів Державної служби із надзвичайних ситуацій засобами IКТ (Ткаченко Т. В., 2009); дослідниця О. Мацюк виокремила педагогічні умови формування професійної компетентності перекладачів засобами ІКТ (Мацюк О. О., 2011).

Не залишились осторонь цього питання i дослідники військової педагогіки, які займаються питаннями реформування змісту, пошуку нових ефективних фрорм, методів і засобів підготовки майбутніх офіцерів Збройних Сил України, зокрема і з використанням засобів ІКТ. Так, педагогічні умови формування професійної компетентності майбутніх магістрів військового управління із застосуванням технології імітаційного моделювання досліджувала Л. Заїка (Заїка Л., 2019); О. Євсюков обгрунтував та експериментально перевірив педагогічні умови, які сприяють формуванню професійної компетентності майбутніх офіцерів у процесі навчальної діяльності (Євсюков О., 2007, с. 12);

За твердженням Л. Грицюк та М. Сірук, самостійна навчальна робота є такою, що плануеться, виконуеться відповідно до поставлених завдань під керівництвом науково-педагогічного працівника, але без його безпосередньої участі, та є основним засобом засвоєння навчального матеріалу в позаадуторний час (Грицюк Л. К., \& Сірук М. В., 2011, с. 11).

На переконання Л. Журавської, самостійна робота передбачає досягнення низки цілей, серед яких виховання самостійності як важливої якості особистості; набуття умінь та навичок виконання самостійної роботи; формування умінь приймати рішення, визначати способи і методи вирішення поставлених завдань, а також здобуття знань, фрормування умінь та навичок (Журавська Л. М., 2009, с. 84).

Для ефективної організації самостійної роботи здобувачів освіти важливим суб’єктом є викладач, який мае іï спланувати, і результативність якої залежить значною мірою від його професіоналізму та методичної майстерності. Тому він повинен чітко та правильно організувати виконання студентами самостійної роботи, логічно визначити завдання на всіх етапах навчання, що дасть змогу активізувати 
навчальну пізнавальну діяльність студентів, змотивуе їх до отримання нових знань, забезпечить самодисципліну та самоорганізацію (Лучкевич В. В., \& Кемінь Г. М., 2013).

Розкриваючи тенденщії використання технології програмно-імітаційних тренажерів для професійної підготовки військовослужбовців О. Шишка акцентуе увагу на провідних з них, як-от: «розширення сфери ïx застосування 3 метою підготовки фрахівців різних військових спеціальностей; вдосконалення та «ускладнення» тренажерів; модернізація програмно-апаратного комп'ютерного забезпечення навчальних закладів; технічне розроблення програм набагато випереджає психолого-педагогічні дослідження; поступова заміна самостійною роботою з програмно-імітаційними тренажерами все більшої кількості практичних занять» (Шишка О., 2014).

Дослідник Ю.Мельничук зауважуе, що проєктна діяльність - це діяльність, спрямована на досягнення мети шляхом детальної розробки проблеми або технології, яка повинна закінчитись певним практичним результатом, що необхідно оформити. Змістом проектної діяльності $є$ перенесення відповідних знань, умінь та навичок у якісно-кількісний формат. Проектна діяльність та проектне мислення становлять основу проектної культури. Ключовою характеристикою проектної діяльності $є$ здатність планувати, перетворювати на основі заздалегідь продуманих проектів (Мельничук Ю., 2018, c. 358).

Висновки / Conclusions. Як узагальнення можемо констатувати, що під поняттям «організаційнопедагогічні умови підготовки МОМП засобами ІКТ» ми розуміємо організаційно-педагогічні заходи, форми, методи, засоби освітньої діяльності у ВВНЗ, які у своїй сукупності вплинуть на досягнення результативності навчання за допомогою сучасних засобів IКТ.

Таким чином, усе вищезазначене дає підстави стверджувати, що дотримання виокремлених та обгрунтованих організаційно-педагогічних умов (організащія самостійної роботи курсантів засобами IКТ; впровадження сучасних комп'ютерно оріентованих методів та засобів організації освітнього процесу у ВВНЗ; використання методу проєктів в професійній підготовці майбутніх офіцерів) дасть змогу підвищити ефрективність підготовки МОМП засобами ІКТ.

\section{Список використаних джерел:}

Гончаренко, С. (1997). Украӥнський педагогічний словник. Київ. [in Ukrainian]

Грицюк, Л. К., \& Сірук, М. В. (2011). Організація самостійної роботи студентів у навчальному процесі вищого навчального закладу. Науковий вісник Волинського національного університету імені Лесі Українки, 17, 9-14. [in Ukrainian]

Доброштан, О. О. (2016). Комп’ютерно-оріентована методична система викладання вищої математики для майбутніх судноводіїв. (Дис. ... канд. пед. наук): 13.00.02. Херсон. [in Ukrainian]

Свсюков, О. Ф. (2007). Педагогічні умови форлування професійної колпетентності майбутніх офбіцерів у навчальному процесі вищого військового навчального закладу. (Автореф. ... дис. канд. пед. наук): 13.00.04. Харків. [in Ukrainian]

Журавська, Л. М. (2009). Компетенції викладача в управлінні самостійною роботою студентів. Вісник Національного технічного університету України "Київський політехнічний інститут». Сер.: Філософбія, психологія, педагогіка, 3, 84-93. [in Ukrainian]

Заїка, Л. А. (2019). Формування професійної колпетентності майбутніх магістрів військового управління із застосування.м технологї̈ імітаційного моделювання. (Автореф. ... дис. канд. пед. наук): 13.00.04. Kиїв. [in Ukrainian]

Кос, М. В. (2018). Імітаційне моделювання в процесі професійної підготовки майбутніх офіцерів тактичного рівня як науково-педагогічна проблема. Young Scientist, 5 (57), 49-53. [in Ukrainian] Russian]

Курлянд, З. Н. (1992). Педагогические способности и профессиональная устойчивость учителя. Одесса. [in

Лучкевич, В. В., \& Кемінь, Г. М. (2013). Організація самостійної роботи студентів у процесі навчання іноземної мови у вищій школі. Вісник Чернігівського національного педагогічного університету. Сер.: Педагогічні науки, 108.2. [in Ukrainian]

Маслій, О. (2019). Організація самостійної навчальної діяльності майбутніх офіцерів ракетно-артилерійського озброення. Педагогіка безпеки, 1, 54-65. [in Ukrainian]

Мацюк, О.О. (2011). Формування проббесійної компетентності майбутніх перекладачів засобами інфборлаційно-комунікаційних технологій. (Автореф. ... дис. канд. пед. наук): 13.00.04. Хмельницький. [in Ukrainian]

Мельничук, Ю. П. (2018). Критерії, показники та рівні сформованості проектно-аналітичної компетентності майбутніх офріеерів-прикордонників. Молодий вчений, 1 (53), 357-361. [in Ukrainian]

Оргеева, С. В. (2016). Педагогічні умови формування готовності студентів-майбутніх авіадиспетчерів до особистого здоров'язбереження у професійній діяльності. Вісник Національного авіаційного університету. Сер.: Педагогіка, Психологія, 8. [in Ukrainian]

Словник-довідник з профбесійної педагогіки. (2006). (Ред.-упоряд. А. А. Семенова). Одеса. [in Ukrainian]

Ткаченко, Т. В. (2009). Форлування професійної колпетентності майбутніх фбахівиів безпеки життедіяльності засобали інфорлаційно-колунікаційних технологій. (Автореф. ... дис. канд. пед. наук): 13.00 .04$. Вінниця. [in Ukrainian]

Филособская энциклопедия. (1964). (Ред. Ф. В. Константинов). Москва. [in Russian]

Філософбський словник. (1986) (Ред. В. І. Шинкарук). Київ. [in Ukrainian]

Шишка, О. Ю. (2014). Основні напрями розвитку технології програмно-імітаційних тренажерів у сфері професійної освіти військовослужбовців. Інфорлаційні технологї $і$ засоби навчання, 42 (4), 159-167. [in Ukrainian]

References:

Honcharenko, S. (1997). Ukrainskyi pedahohichnyi slovnyk [Ukrainian Pedagogical Dictionary]. Kyiv. [in Ukrainian] Hrytsiuk, L. K., \& Siruk, M. V. (2011). Orhanizatsiia samostiinoi roboty studentiv u navchalnomu protsesi vyshchoho 
navchalnoho zakladu [Organization of Independent Work of Students in the Educational Process of Higher Education Institution]. Naukovyi visnyk Volynskoho natsionalnoho universytetu imeni Lesi Ukrainky - Scientific Bulletin of Lesia Ukrainka Volyn National University, 17, 9-14. [in Ukrainian]

Dobroshtan, O. O. (2016). Kompiuterno-oriientovana metodychna systema vykladannia vyshchoi matematyky dlia maibutnikh sudnovodiiv [Computer-Based Methodological System of Teaching Higher Mathematics for Future Navigators]. (Candidate's thesis): 13.00.02. Kherson. [in Ukrainian]

Yevsiukov, O. F. (2007). Pedahohichni umovy formuvannia profesiinoi kompetentnosti maibutnikh ofitseriv $u$ navchalnomu protsesi vyshchoho viiskovoho navchalnoho zakladu [Pedagogical Conditions for the Formation of Professional Competence of Future Officers in the Educational Process of Higher Military Education]. (Extended abstract of Candidate's thesis): 13.00.04. Kharkiv. [in Ukrainian]

Zhuravska, L. M. (2009). Kompetentsii vykladacha v upravlinni samostiinoiu robotoiu studentiv [Competences of the Teacher in Management of Independent Work of Students]. Visnyk Natsionalnoho tekhnichnoho universytetu Ukrainy "Kyivskyi politekhnichnyi instytut». Ser.: Filosofiia, psykholohiia, pedahohika - Bulletin of the National Technical University of Ukraine "Kyiv Polytechnic Institute». Ser.: Philosophy, Psychology, Pedagogy, 3, 84-93. [in Ukrainian]

Zaika, L. A. (2019). Formuvannia profesiinoi kompetentnosti maibutnikh mahistriv viiskovoho upravlinnia iz zastosuvanniam tekhnolohii imitatsiinoho modeliuvannia [Formation of Professional Competence of Future Masters of Military Management with the use of Simulation Technology]. (Extended abstract of Candidate's thesis): 13.00.04. Kyiv. [in Ukrainian]

Kos, M. V. (2018). Imitatsiine modeliuvannia v protsesi profesiinoi pidhotovky maibutnikh ofitseriv taktychnoho rivnia yak naukovo-pedahohichna problema (Simulation Modeling in the Process of Professional Training of Future Officers of the Tactical Level as a Scientific and Pedagogical Problem). Young Scientist, 5 (57), 49-53. [in Ukrainian]

Kurliand, Z. N. (1992). Pedagogicheskie sposobnosti i professional'naya ustojchivost' uchitelya [Pedagogical Abilities and Professional Stability of the Teacher]. Odessa. [in Russian]

Luchkevych, V. V., \& Kemin, H. M. (2013). Orhanizatsiia samostiinoi roboty studentiv u protsesi navchannia inozemnoi movy u vyshchii shkoli [Organization of Independent Work of Students in the Process of Learning a Foreign Language in High School]. Visnyk Chernihivskoho natsionalnoho pedahohichnoho universytetu. Ser.: Pedahohichni naukyBulletin of Chernihiv National Pedagogical University. Ser.: Pedagogical Sciences, 108.2. [in Ukrainian]

Maslii, O. (2019). Orhanizatsiia samostiinoi navchalnoi diialnosti maibutnikh ofitseriv raketno-artyleriiskoho ozbroiennia [Organization of Independent Training Activities for Future Missile and Artillery Officers]. Pedahohika bezpeky Security Pedagogy, 1, 54-65. [in Ukrainian]

Matsiuk, O. O. (2011). Formuvannia profesiinoi kompetentnosti maibutnikh perekladachiv zasobamy informatsiinokomunikatsiinykh tekhnolohii [Formation of Professional Competence of Future Translators by Means of Information and Communication Technologies]. (Extended abstract of Candidate's thesis): 13.00.04. Khmelnytskyi. [in Ukrainian]

Melnychuk, Yu. P. (2018). Kryterii, pokaznyky ta rivni sformovanosti proektno-analitychnoi kompetentnosti maibutnikh ofitseriv-prykordonnykiv [Criteria, Indicators and Levels of Formation of Project-Analytical Competence of Future Border Guards]. Molodyi vchenyi - Young Scientist, 1 (53), 357-361. [in Ukrainian]

Orhieieva, S. V. (2016). Pedahohichni umovy formuvannia hotovnosti studentiv-maibutnikh aviadyspetcheriv do osobystoho zdoroviazberezhennia u profesiinii diialnosti [Pedagogical Conditions for the Formation of Readiness of StudentsFuture Air Traffic Controllers for Personal Health in Professional Activities]. Visnyk Natsionalnoho aviatsiinoho universytetu. Ser.: Pedahohika, Psykholohiia - Bulletin of the National Aviation University. Ser.: Pedagogy, Psychology, 8. [in Ukrainian]

Slovnyk-dovidnyk z profesiinoi pedahohiky [Dictionary of Professional Pedagogy]. (2006). (Ed. A. A. Semenova). Odesa. [in Ukrainian]

Tkachenko, T. V. (2009). Formuvannia profesiinoi kompetentnosti maibutnikh fakhivtsiv bezpeky zhyttiediialnosti zasobamy informatsiino-komunikatsiinykh tekhnolohii [Formation of Professional Competence of Future Life Safety Specialists by Means of Information and Communication Technologies]. (Extended abstract of Candidate's thesis): 13.00 .04 . Vinnytsia. [in Ukrainian]

Filosofskaya e'nciklopediya [Philosophical encyclopedia]. (1964). (Ed. F. V. Konstantinov). Moscow. [in Russian]

Filosofskyi slounyk [Philosophical Dictionary]. (1986). (Ed. V. I. Shynkaruk). Kyiv. [in Ukrainian]

Shyshka, O. Yu. (2014). Osnovni napriamy rozvytku tekhnolohii prohramno-imitatsiinykh trenazheriv u sferi profesiinoi osvity viiskovosluzhbovtsiv [The Main Directions of Development of Technology of Software and Simulation Simulators in the Field of Professional Education of Servicemen]. Informatsiini tekhnolohii $i$ zasoby navchannia Information Technologies and Teaching Tools, 42 (4), 159-167. [in Ukrainian]

Дата надходження статті: «16» жовтня 2020 р.

Стаття прийнята до друку: «10» грудня 2020 р.

Зайцев Ігор - доцент кафедри тактики та загальновійськових дисциплін Військової академії (м.Одеса)

Zaitsev Ihor - Assistant Professor of the Department of Tactics and General Military Disciplines of Military Academy (city of Odesa)

\section{Цитуйте ию статтю як:}

Зайцев, I. (2020). Організаційно-педагогічні умови підготовки майбутніх офіцерів морської піхоти засобами інформаційно-комунікаційних технологій. Педагогічний дискурс, 29, 82-87. oi: $\underline{10.31475 / \text { ped.dys.2020.29.11. }}$.

\section{Cite this article as:}

Zaitsev, I. (2020). Organizational-Pedagogical Conditions of Training Future Naval Infantry Units Officers by Means of Information-Communication Technologies. $\begin{array}{llll}\text { Pedagogical Discourse, } & 29, & 82-87 .\end{array}$ doi: 10.31475/ped.dys.2020.29.11. 